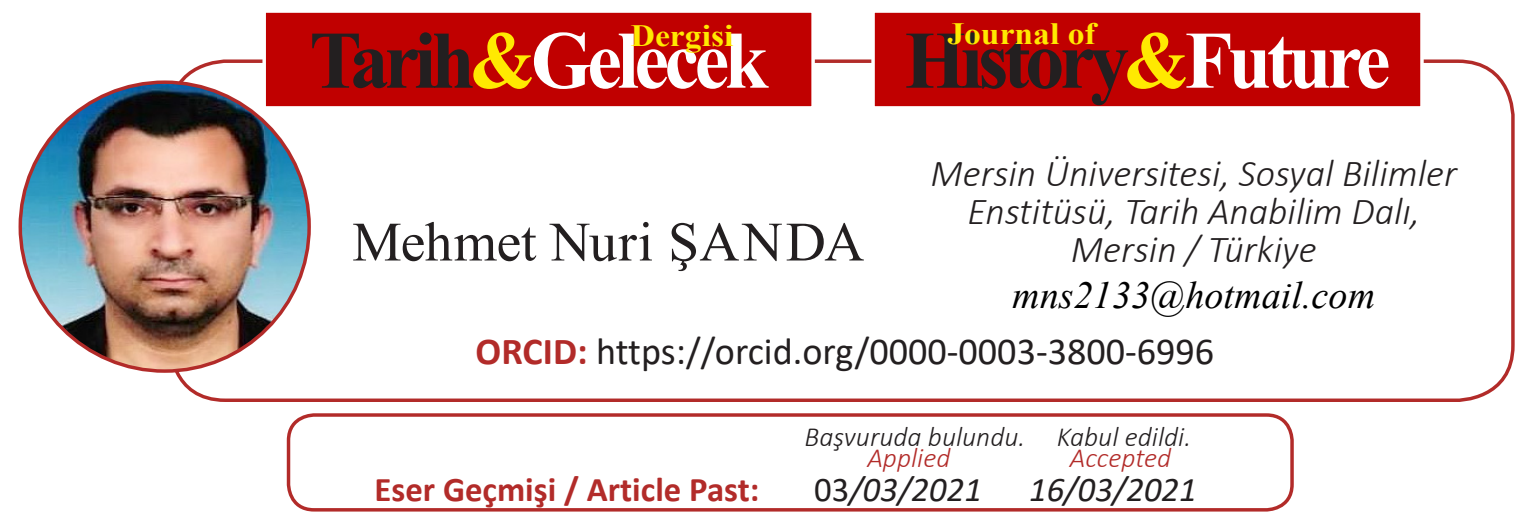

Araştırma Makalesi

DOI: http://dx.doi.org/10.21551/jhf.889878

Research Paper

Orjinal Makale / Orginal Paper

\title{
20. Yüzyılda Ceylanpınar Çiftliği
}

\section{$\ddot{O} z$}

\section{Ceylanpinar Farm in the 20th Century}

Bu çalışmanın amacı CeylanpınarÇiftliği'nin 20. yüzyıldaki durumunu arşiv belgeleri ve araştırma-inceleme eserler 1şı̆̆ında ele alınmaktır. Bu amaç doğrultusunda Cumhuriyet Arşivi’nde bulunan belgeler incelenmiş ve konu ile ilgili olanlar araştırmaya aktarılmıştır. Araştırmada ele alınan konular bölümler halinde açıklanmıştır. Makalenin giriş bölümünde yeni kurulan Türk Devleti’nin ekonomik bağımsızlığını sağlamak amacıyla attığı adımlar, tarım ve hayvancılığı geliştirmek için kurduğu kurumlar hakkında bilgilere yer verilmiştir. Birinci bölümde Ceylanpınar'ın belediye ve ilçe olması üzerinde durulmuştur. İkinci bölümde ise Ceylanpınar Çiftliği’nin ne zaman kurulduğuna, çiftliğe "Ceylanpınar" adının niçin ve hangi tarihte verildiğine, 20. yüzyılda çiftlikte yapılan tarım ve hayvancılık faaliyetlerine, çiftlik içinde haberleşme sorununun çözülmesine, Ceylanpınar'da içme ve sulama suyu sorununun çözülmesine, nesli tükenmekte olan ceylanların koruma altına alınmasına ve çiftliğe yerleştirilen mültecilerin hangi imkânlarla yerleştirildiğine değinilmiştir. Ceylanpınar Çiftliği hakkında daha önce bu tür bir çalışma yapılmadığı için araştırmanın literatürde bir boşluğu dolduracağı düşünülmektedir.

Anahtar Kelimeler: Urfa, Ceylanpınar, Resulayn, Çiftlik.

\section{Abstract}

The purpose of this study is to discuss the situation of Ceylanpinar Farm in the 20th century under the light of archival documents and research investigation. In accordance with this purpose, the documents found in the Republic Archives are studied and those related to the topic are transported for research. The present research topics are explained in chapters. In the introductory chapter, information is given about the steps taken by the newly established Turkish State to secure its economic independence and the institutions it established to develop agriculture and livestock. In the first chapter, it is pointed out that Ceylanpinar becoming a municipality and a district. In the second chapter, it is pointed out when Ceylanpinar Farm was established, why and on what date it was named "Ceylanpınar", what activities were carried out in the farm for agriculture and livestock in the 20th century, how the communication problem within the farm was solved, how the drinking and irrigation water problem of Ceylanpinar was solved, the endangered gazelles that were put under protection, and the opportunities for the resettlement of the refugees in the farm. Since there has been no such study on Ceylanpinar Farm, this research aims to fill a gap in the literature.

Keywords: Urfa, Ceylanpınar, Resulayn, Farm. 


\section{Giriş}

20. yüzyılın ilk yarısında meydana gelen I. Dünya Savaşı ve Kurtuluş Savaşı'nda çok sayıda insan ölmüştür. Bu durum Anadolu' da tarım ve hayvancılık başta olmak üzere birçok alanı olumsuz etkilemiştir. İnsan gücünün azlığının yanında tarım ve hayvancılıkta verimi düşüren başka faktörler de bulunmaktadır. Bu faktörlere kaliteli tohumun az oluşu ve var olan insan gücünün bilinçli tarım uygulamalarından habersiz olması da örnek gösterilebilir.

Siyasal anlamada bağımsızlığını kazanan Türk Devleti, ekonomik bağımsızlı̆̆ını güçlendirmek, çiftçinin bilinçlenmesini sağlamak, tarım ve hayvancılık alanlarında verimi artırmak amacıyla birçok girişimde bulunmuştur. Bu doğrultuda 1924'te Tarım Kredi Birlikleri Kanunu çıkarılmış, 1925'te çiftçinin vergi yükünü hafifletmek amacıyla Aşar vergisi kaldırılmış, 1929'da Tarım-Kredi Kooperatifleri, 1933'te Yüksek Ziraat Enstitüleri, 1937'de Zirai Kombinalar, 1938'de Devlet Ziraat İşletmeleri ve Toprak Mahsulleri Ofisi kurulmuştur. 1943 yılında 10 milyon sermaye ile Türkiye Zirai Donatım Kurumu oluşturulmuştur. ${ }^{1}$ Bu kurumun temel görevi tarım alanında çiftçiye gerekli olan makine, alet, ilaç ve gübrenin teminini sağlamaktır. ${ }^{2} 1949$ yılında Ceylanpınar Çiftliği'nin de bağlı olduğu Devlet Üretme Çiftlikleri kurulmuştur. ${ }^{3}$ Gerçekleştirilen bu faaliyetlerle bir taraftan çiftçinin bilgi birikimi artırılmaya çalışılmış diğer taraftan da tarım ile hayvancılıkta üretim ve kalite artırılmaya çalışılmıştır.

Ceylanpınar Çiftliği’nin, ülke ekonomisinin kalkınmasında ve tarımın gelişmesinde büyük katkıları olmuştur. Bu çalışmada ülkemizin en büyük çiftliği olan Ceylanpınar Çiftliği’nin kurulması, gelişmesi ve üretim faaliyetleri üzerinde durulmuştur. Literatürde yapılan eser ve makale taramalarında daha önce Ceylanpınar çiftliği ile ilgili bu tür bir çalışmanın yapılmadığ 1 görülmüştür. Bu sebepten dolayı çalışmanın alana katkı sağlayacağı da düşünülmektedir.

\section{Ceylanpınar'ın Belediye ve İlçe Olması}

Güney cephesinde Fransız ve Ermenilere karşı girişilen Kurtuluş Savaşı'nda Urfa ve Ceylanpınar toprakları işgalden kurtarılmıştır. 20 Ekim 1921 tarihinde Fransızlarla imzalanan Ankara Anlaşması kapsamında Türkiye ile Suriye arasındaki sınır hattı Çobanbey İstasyonu'ndan Nusaybin'e kadar uzanan demiryolu olarak belirlenmiştir. Bu anlaşmaya göre Rasulayn merkezinin bir kısmı Suriye topraklarında bir kısmı ise Türkiye topraklarında kalmıştır. Anlaşma gereğince tren hattının güneyinde kalan bazı aşiretler ve Rasulayn'daki Çeçen aileler Türk vatandaşlığına kabul edilmiştir. ${ }^{4}$

13 Şubat 1924 tarihinde TBMM'nin çıkardığ 532 numaralı kanunla Mardin ili dâhilinde Rasulayn kazası kurulmuştur. ${ }^{5} 3$ Nisan 1924 tarihinde de Başbakanlık tarafindan İçişleri Bakanlığına gönderilen bir kararla Türkiye tarafında kalan Rasulayn kazasının Mardin'e bağlı

1 Nadir Yurtoğlu, "Cumhuriyet Dönemi Ziraatta Makineleşme Sürecinde Türkiye Zirai Donatım Kurumunun (TZDK) Yeri ve Önemi (1943-1960)”, Tarih Okulu Dergisi, XXIX, (2017): 282.

2 İlhan Tekeli ve Selim İlkin, “1929 Dünya Buhranında Türkiye'nin İktisadi Politika Arayışları”, Cilt 1, (Bilge Kültür Sanat Yayınevi, 2009), 145-146.

3 Resmi Gazete, Say1 No: 7231, 13 Haziran 1949.

$4 \quad$ BCA, 30.18.1.1/5.17.10, (25 May1s 1338).

5 TBMM Kanunlar Dergisi, 2.Dönem Kanunları, 11.Cilt, 21.Birleşim, 116. 
kalma statüsü devam ettirilmiştir. ${ }^{6} 15$ Şubat 1925 tarihinde Cumhurbaşkanı Mustafa Kemal'in imzasıyla Şirvan kaymakamı Mustafa Bey, Rasulayn kaymakamlığına tayin edilmiştir. ${ }^{7}$ Yine 16 Ocak 1929 tarihinde Mustafa Kemal'in imzasıyla Rasulayn kaymakamlığına İsmail Bey adında bir idareci tayin edilmiştir. ${ }^{8}$

7 Nisan 1925 tarihinde Mardin iline bağlı Rasulayn kazasının çok yakınında bulunan Tel Haref köyündeki Hitit harabelerinde bir miktar tarihi eser bulunmuştur. Bu köy 20 Ekim 1921 tarihinde imzalanan Ankara Antlaşması ile Suriye sınırları içinde kalmıştır. Bu köyün zengin bir tarihe ve kültürel mirasa sahip olduğunu gören Türk idareciler Tel Haref köyünün Türkiye sınırlarına dâhil edilmesi için yoğun çaba harcamışlarsa da neticede bu köy Suriye topraklarında kalmıştır. ${ }^{9}$

Rasulayn kazası, 17 Nisan 1929'da Bakanlar Kurulunun aldığı bir kararla Mardin ilinin Koçhisar kazasına bağlı bir nahiye statüsüne çekilmiştir. ${ }^{10} 17$ Mart 1930'da İçişleri Bakanlığ tarafından Cumhurbaşkanlığına ve Başbakanlığa yazılan bir yazıda Rasulayn nahiyesinin, Mardin iline bağl1 Koçhisar kazasına uzak olduğu ve bu durumun birçok sıkıntıya neden olduğu belirtilmiştir. Ayrıca Rasulayn nahiyesinin, Urfa'ya bağlı Viranşehir kazasına yakın olduğu, Rasulayn ile Viranşehir arasında telefon tesisatının bulunduğu belirtilerek Rasulayn'ın Viranşehir'e bağlanması talep edilmiştir. ${ }^{11}$ İçişleri Bakanlığg'nın bu talebi 18 Mart 1930' da Cumhurbaşkanı Mustafa Kemal ve Başbakan İsmet İnönü'nün onayıyla kabul edilmiştir. ${ }^{12}$

1955 yılındaki nüfus sayımında Ceylanpınar nahiyesinin merkezi olan Ceylanpınar Köyü’nün nüfusu 4.682 kişidir. Aynı yıl Ceylanpınar köyünün belediye olmasına yönelik yapılan halkoylamasında 2.797 seçmenden 2.616'sı oy kullanmış ve bunlardan 2.613'ü Ceylanpınar köyünün belediye olmasını istemiştir. Ayrıca köyün ihtiyar heyeti, Ceylanpınar'ın belediye olması için Urfa Valiliği'ne müracaat etmiş ve ihtiyar heyetinin bu müracaatı üzerine Urfa İl Genel Meclisi, 15 Aralık 1958'de Ceylanpınar nahiyesinin merkezi olan Ceylanpınar köyünün, Belediye’ye dönüştürülmesine karar vermiştir. Şanlıurfa Valiliği, İl Genel Meclisi’nin aldığı bu kararı İçişleri Bakanlığı'na göndermiştir. İçişleri Bakanlığı da kendisine gelen bu kararı Devlet Şûrası Reisliği’ne iletmiştir. 26 Nisan 1959'da Devlet Şurası Genel Heyeti tarafından Ceylanpınar köyünün belediyeye dönüştürülmesi yönünde karar alınmıştır. Bu karar 25 Mayıs 1959'da Cumhurbaşkanının onayı ile yürürlüğe girmiştir. ${ }^{13}$ Ceylanpınar, 14 Ocak 1982'de TBMM tarafından çıkartılan 2585 Sayılı Kanun doğrultusunda ilçe statüsüne yükseltilmiştir. ${ }^{14}$

\footnotetext{
$6 \quad$ BCA, 30.18.1.1/9.19.13, (03 Nisan 1340).

$7 \quad$ BCA, 30.11.1.0/10.6.1, (15.02.1925).

$8 \quad$ BCA, 30.11.1.0/45.43.4, (16.01.1929).

9 BCA, 30.10.0.0/146.42.3. (07.04. 1925).

$10 \quad$ BCA, 30.18.01.02.3.22.11, (17 Nisan 1929).

11 BCA, 30.11.01/54.8.3, (17 Mart 1930).

12 BCA, 30.11.01/54.8.3, (18 Mart 1930).

13 BCA, 30.11.01/275.13.6, (08 Nisan 1959).

14 Elif Atar ve M. Fatih Eslemez, Ceylanpınar'ın İlçe Durum Raporu, (Şanlıurfa: Karacadağ Kalkınma Ajansı Yayınları, 2011), 4.
} 


\section{20. Yüzyılda Ceylanpınar Çiftliği}

\subsection{Ceylanpınar Çiftliği'nin Kurulması}

12 Şubat 1937'de çıkarılan 3130 sayılı kanunla Zirai Kombinalar kurulmuştur. Bu kombinaların kurulma nedeni tarım alanında makineleşmeyi sağlamak, verimi artırmak ve çiftçinin refah seviyesini yükseltmektir. ${ }^{15}$ Aynı yıl Zirai Kombinalar bünyesinde "Urfa Grup Amirliği" kurulmuştur. Ceylanpınar'daki çiftlik, bu amirliğe bağlı olarak 1943 yılında açılmıştır. Ceylanpınar çiftliği, 1 Mart 1950 yılında yürürlüğe giren 5433 sayılı kanun doğrultusunda Devlet Üretme Çiftliği Genel Müdürlüğüne bağlanmıştır. 1984 yılında Haralar ve İnekhanelerin, Devlet Üretme Çiftlikleri ile birleşmesi sonucunda Kamu İktisadi Teşebbüs olarak kurulan Tarım İşletmeleri Genel Müdürlüğüne bağlanmıştır. ${ }^{16}$

\section{2. Çiftliğe "Ceylanpınar" Adının Verilmesi}

Türkiye Cumhuriyeti'nin kurulmasından sonra siyaset sahasında milli ve yerli bir görüş hakim olmaya başlamıştır. Bu durum idari, sosyal ve kültürel alanlarda birçok değişimin yaşanmasına ortam hazırlamıştır. Bu değişimlerden biri de Arapça olan "Rasulayn" isminin "Ceylanpınar” olarak değiştirilmesidir.

İçişleri Bakanlığı tarafından 4 Nisan 1946'da Cumhurbaşkanlığına ve Başbakanlığa gönderilen yazıda, Urfa ilinin Viranşehir ilçesine bağlı Rasulayn Bucağı, Rasulayn köyü ve Rasulayn Tren İstasyonu adlarının Arapça olduğu; bu bucak, köy ve istasyon merkezinin güneyinde Rasulayn adıyla başka bir yerleşim biriminin bulunduğu ve bu durumun karışıklığa neden olduğu belirtilmiştir. Bu karışıklığın giderilmesi için Rasulayn Bucağında bulunan Zirai Kombinalar İşletmesinin "Ceylanpınar Çiftliği " adıyla bir devlet çiftliğine dönüştürülmesi ve Arapça olan bu bucak, köy ve tren istasyonu isimlerinin de "Ceylanpınar" şeklinde değiştirilmesi istenmiştir. İlk olarak Urfa Valiliği tarafından Tarım Bakanlığı'na yapılan bu teklif, Tarım Bakanlığı tarafından da içişleri Bakanlığı ve Ulaştırma Bakanlığına iletilmiştir. İki bakanlığın teklife olumlu cevap vermesi üzerine İçişleri Bakanlığının girişimiyle 11 Nisan 1946'da Cumhurbaşkanı, Başbakan ve ilgili bakanın onayıyla teklif kabul edilmiştir. Böylece Urfa ili Viranşehir İlçesine bağlı Rasulayn bucağ1, köyü ve istasyonunun adı "Ceylanpınar" olarak değiştirilmiştir. ${ }^{17}$

\section{3. Çiftliğin Kira Bedelinin Takibi}

Osmanlı Devleti'nde çiftlikler açık artırma yoluyla fiyat, kârlılık ve verimlilik ilkelerine uygun olarak belli bir süreliğine mültezimlere kiraya verilmiştir. Devletin bu çiftlikleri kiraya verme nedeni toprakların verimli bir şekilde kullanılmasını sağlamak ve hazinenin nakit ihtiyacını karşılamaktır. Bazı dönemlerde mültezimler zarar edeceklerini anladıklarında çiftlikleri terk ederek, devlete ödemeleri gerek ücretleri ödememişlerdir. Yeni kurulan Türk Devleti, Osmanlı Devleti'nden kalma çiftlik kira bedellerini ödemeyen mültezimler ve kefilleri hakkında çeşitli muamelelerde bulunmuştur. Bu doğrultuda Beyrut Vilayetine bağlı Rasulayn Çiftliği'ni kiralayan İskender ve Maron Nemurun adlı şahıslar 1875 ve 1876 yıllarına ait kira borçları olan 2006 lira 42

15 Nadir Yurtoğlu, "II. Dünya Savaşı Dönemi ve Sonrasında Ziraî Kombinalar Tarihi Hakkında Bir İnceleme (1937-1949)", international Journal Of History Studies, 10/4, (June 2018): 219-249.

16 Tarım İşletmeleri Genel Müdürlüğü, Ceylanpınar Çiftliği-Dünden Bugüne Tigem (Türk Toplumunun Yüz Akl), (Ankara: TİGM Yayınları, 2013), 69.

17 BCA, 30.11.01/182.13.11, (11 Nisan 1946). 
kuruşu devlete ödememişlerdir. Belirtilen kira bedelinin, kiracıların kefili olan Saydalı Abdülhay ve Abdülhalim Lütfü'den tahsil edilmesi için Sayda Bidayet Mahkemesine dava açılmıştır. 11 Mart 1891'de Sayda Bidayet Mahkemesi davanın reddine ve verilen haczin bir üst mahkemeye gönderilmesine karar vermiştir. Sayda Bidayet Mahkemesi'nin bu kararı 1900 yılında Beyrut İstinaf Mahkemesince fesih edilmiş ve belirtilen paranın tahsil edilerek hazineye aktarılması istenmiştir. Beyrut İstinaf Mahkemesince verilen bu karar Abdülhay ve Abdülhalim Lütfü tarafindan 26 Mayıs 1900 tarihinde temyiz edilmiştir. Temyiz edilen karara ait dosya Adliye yangınında yandığ 1 için kararın uygulanması mümkün olmamıştır. Yeni kurulan Türk Devleti, Rasulayn Çiftliği'nin dava konusu olan meblağlarını tahsil etmek için belli bir süre davaları takip etmiştir. Fakat yukarıdaki sebeplere ek olarak dava üzerinden epeyce bir zaman geçmesi, asıl borçlu olan İskender ile Maron Nemurun adlı kişilerin bulundukları memleketlerin Türkiye Cumhuriyeti dışında kalması ve adreslerinin de tam olarak bilinmemesinden dolayı 3 Haziran 1936'da davanın takibinden vazgeçilmiştir. ${ }^{18}$

\section{4. Çiftlikte Modernleşme Çalışmaları}

Tarımsal faaliyetler 1940 yılından önce daha çok klasik yöntemlerle yürütülmüştür. 1940 yılında 3780 sayılı Milli Korunma Kanunu doğrultusunda Zirai Kombinalar Kurumu 10 milyon liralık kredi ile makineleşme yoluna gitmiştir. Böylece tarımsal üretim alanında yeni bir dönem başlamıştır. Satın alınan makineler ilk olarak Urfa'daki Ceylanpınar, Ankara'daki Balâ ve Polatlı, Amasya'daki Gökhüyük, Konya'daki Altınova, Özden ve Gözlü, Sivas’taki Ulaş, Kırşehir'deki Çiçekdağı ve Malya, Samsun'daki Gelemen, Niğde'deki Koçaş ile Kayseri'deki Keykubat bölgesinde kurulan işletmelerde kullanılmıştır. ${ }^{19}$

1948 yılında yürürlüğe konan Marshall yardımı ile Urfa'ya birçok makine ve tarım aleti sevk edilmiştir. Bu aletler içerisinde 27 adet kendinden yürür ve 10 adet de traktörle çekilen biçerdöver, 61 pulluk ve 56 traktör yer almaktadır. Bu makinelerin sevk ve idaresi için bilgili makinistler yetiştirmek amacıyla 10 Haziran 1949 tarihinde Ceylanpınar Devlet Üretme Çiftliği'nde 100 kursiyerin katılabileceği ücretsiz bir kurs açılmıştır. Bu kursiyerlerin iaşesi Bakanlık tarafından karşılanmıştır. Kursu başarıyla bitirenlere tarım makineleri kullanabilme ehliyeti verilmiştir. ${ }^{20}$

1965 yılında Devlet Üretme Çiftlikleri Genel Müdürlüğü bünyesindeki çiftliklere çeşitli yatırımlar yapılmıştır. Zikredilen yılda Urfa'daki Ceylanpınar Devlet Üretme Çiftliği'ne de bazı yatırımlar gerçekleştirilmiştir. Gerçekleştirilen bu yatırımlar aşağıdaki tabloda verilmiştir.

18 BCA, 30.11.1.0/104.17.10, (3 Haziran 1936).

19 Nadir Yurtoğlu, "II. Dünya Savaşı Dönemi ve Sonrasında Ziraî Kombinalar Tarihi Hakkında Bir İnceleme (1937-1949)", international Journal Of History Studies, 10/4, (June 2018): 219-249.

20 Ferit Yücebaş, “Cumhuriyet Döneminde Güneydoğu Anadolu (Gaziantep-Mardin-Urfa)'ya Yapılan Kamu Harcamaları ve Yatırımlar (1923-1950)", Yayımlanmamış Doktora Tezi, Bitlis Eren Üniversitesi/ Erciyes Üniversitesi, (2018), 416-417. 
Tablo 1. 1965 Yılında Ceylanpınar Devlet Üretme Çiftliği’ne Yapılan Yatırımlar

\begin{tabular}{|c|c|c|c|c|}
\hline $\begin{array}{l}\text { İşletme } \\
\text { Adı }\end{array}$ & Proje Adı & $\begin{array}{c}\text { Program } \\
\text { Tutarı } \\
\text { (TL) }\end{array}$ & $\begin{array}{c}\text { İhale } \\
\text { Bedeli } \\
\text { (TL) }\end{array}$ & Yapılan Yatırımlar \\
\hline \multirow{4}{*}{ 苞 } & Arazi Islahı & 995.000 & 995.000 & $\begin{array}{l}\text { İller Bankası aracılığıyla Habur kabartma bendi ve } \\
\text { yaklaşım bendi yapılmıştır. }\end{array}$ \\
\hline & $\begin{array}{l}\text { Ç a y } 1 \text { r - } \\
\text { Mera }\end{array}$ & 10.000 & 10.000 & 100 dekar Afrika yoncası tesis edilmiştir. \\
\hline & Bağ-Bahçe & - & - & Gelecek senelere sirayet etmektedir. \\
\hline & Zirai İnşaat & 999.000 & 994.200 & $\begin{array}{l}4 \text { adet } 500 \text { taşlık koyun ağılı, } 5 \text { adet 2'li lojman, } 2 \text { adet } \\
\text { bekçi kulübesi, } 4 \text { adet derin kuyu muhafaza bekçi } \\
\text { kulübesi, } 1 \text { adet su yulağı, telefon hattı, } 1 \text { adet makine } \\
\text { parkı, } 1 \text { adet sera binası, } 3.152 \text { metre sınır tahdidi, } \\
1.295 \text { metre Beyazkule işletmesi su kulesi ve şebekesi, } \\
2 \text { adet fosseptik çukuru ve kanalizasyonu, Beyazkule } \\
\text { harici elektrik tesisatı, ilkokul harici şebekeye elektrik } \\
\text { tesisatının bağlantısı yapılmıştır. }\end{array}$ \\
\hline
\end{tabular}

Kaynak: BCA, 30.1.0.0.81.513.4. (00.00.1965).

Yukarıdaki tabloda da görüldüğü üzere 1965 yılında Ceylanpınar Çiftliği’nde 995.000 lira ihale bedeli karşılığında arazi ıslahı gerçekleştirilmiş, 10.000 lira ihale bedeli karşılığında 100 dekarlık alana Afrika yoncası ekilmiş ve 994.200 lira ihale bedeli karşılığında da çiftlik içinde lojman, bekçi kulübesi vb. yatırımları gerçekleştirilmiştir. Gerçekleştirilen bu yatırımlarla çiftlikte çalışan idarecilerle işçilerin çalışma ve yaşam alanları iyileştirilmiştir. Ayrıca 1 adet sera binasının yapılması çiftlikte seracılık faaliyetlerinin yapılmaya başlandığının göstergesidir.

1965 yılında Ceylanpınar Devlet Üretme Çiftliği’ndeki bağ ve bahçelerde yatırımlara başlanmış olup 1966 yılında da devam edilmesi planlanmıştır. Gerçekleştirilmesi planlanan yatırımın bedeli 91.000 Türk lirasıdır. Bu bedel karşılığında 400 dekarlık alana fistık ağacının ekilmesi planlanmıştır. ${ }^{21}$

1967 yılında içinde Ceylanpınar Çiftliği'nin de bulunduğu Devlet Üretme Çiftlikleri Genel Müdürlüğü bünyesindeki çiftliklere döner sermayeden çeşitli yatırımlar gerçekleştirilmiştir. $\mathrm{Bu}$ yatırımlar arasında bağ-bahçe giderleri de bulunmaktadır. Belirtilen yılda ülke genelindeki çiftliklere yapılan yatırım miktarları aşağıdaki tabloda verilmiştir. 
Tablo 2. 1967 Yılında Devlet Üretme Çiftlikleri İçin Döner Sermayeden Ayrılan Yatırım Miktarları

\begin{tabular}{|l|l|l|c|}
\hline İl & İşletme Adı & Projenin Adı & Yatırım Tutarı (TL) \\
\hline Muş & Alparslan Çiftliği & Bağ-Bahçe ve Ağaçlandırma & 25.000 \\
\hline Urfa & Ceylanpınar Çiftliği & Bağ-Bahçe ve Ağaçlandırma & 267.000 \\
\hline Muğla & Dalaman Çiftliği & Bağ-Bahçe ve Ağaçlandırma & 150.000 \\
\hline Samsun & Gelemen Çiftliği & Bağ-Bahçe ve Ağaçlandırma & 33.000 \\
\hline Kars & Iğdır Çiftliği & Bağ-Bahçe ve Ağaçlandırma & 22.000 \\
\hline Konya & Konuklar Çiftliği & Bağ-Bahçe ve Ağaçlandırma & 10.000 \\
\hline Dörtyol & Turunçgiller Çiftliği & Bağ-Bahçe ve Ağaçlandırma & 77.000 \\
\hline Sivas & Ulaş Çiftliği & Bağ-Bahçe ve Ağaçlandırma & 9.000 \\
\hline İstanbul & Yalova Çiftliği & Bağ-Bahçe ve Ağaçlandırma & 140.000 \\
\hline Toplam & & & 733.000 \\
\hline
\end{tabular}

Kaynak: BCA, 30.18.1.2.210.66.10, (02.09.1967)

Yukarıdaki tabloda da görüldüğü üzere 1967 yılında Devlet Üretme Çiftliklerine bağlı Alparslan, Ceylanpınar, Dalaman, Gelemen, Iğdır, Konuklar, Turunçgiller, Ulaş ve Yalova çiftliklerine 733.000 lira bağ-bahçe ve ağaçlandırma yatırımı yapılmıştır. Bu çiftlikler içerisinde en büyük yatırım miktarı 267.000 lira ile Ceylanpınar Çiftliği'ne yapılmıştır.

1967 yılında çiftliklere yapılan yatırımlar sadece bağ-bahçe ve ağaçlandırma faaliyetleri olmayıp bunun dışında çiftliklerin zirai inşaat ve tesisatı ile arazi ıslahı ve sulama hizmetlerine de yatırımlar gerçekleştirilmiştir. Belirtilen yılda Ceylanpınar Devlet Üretme Çiftliği'ndeki arazi 1slahı ve sulama hizmetleri için 2.905.000 Türk lirası, zirai inşaat ve tesisat için de 926.000 Türk lirası yatırım yapılmıştır. ${ }^{22}$

Çiftlikte tarımsal alanda kalite ve verimi artırmak için alınan tedbirlerin yanında hayvancılık alanında da verimi artırmak ve bununla birlikte seracılığı geliştirmek için bazı yatırımlar yapılmıştır. Bu doğrultuda 1970 yılında Ceylanpınar, Türkgeldi, Malya ve Ulaş Devlet Üretme Çiftliklerine 1.500 Türk lirası ödenek ayrılmıştır. ${ }^{23}$

\section{5. Çiftlikteki Tarımsal Faaliyetler}

1946 yılında Ceylanpınar Çiftliği'nde ekilen arazi miktarı 364.000 dönümdür. Aynı yıl bu arazilerin 52.100 dekarına arpa ve 92.500 dekarına da buğday ekilmiştir. ${ }^{24}$ Ekilen bu arazilerden $9.020 .523 \mathrm{~kg}$ arpa ve $5.116 .148 \mathrm{~kg}$ buğday elde edilmiştir. ${ }^{25} 1948$ yılında çiftlik topraklarındaki 140.000 dekarlık alana buğday, 27.000 dekarlık alana beyaz arpa ve 4.000 dekarlık alana da keten tohumu ekilmiştir. ${ }^{26}$ II. Dünya Savaşı'ndan sonra Ankara ve İstanbul'da un sıkıntısından

\footnotetext{
22 BCA, 30.18.1.2.210.66.10, (02.09.1967).

23 BCA, 30.18.1.2.259.81.15, (18 Kasim 1970).

241 dekar $1000 \mathrm{~m}^{2}$ dir.

25 Nadir Yurtoğlu, "II. Dünya Savaşı Dönemi ve Sonrasında Ziraî Kombinalar Tarihi Hakkında Bir İnceleme (1937-1949)", international Journal Of History Studies, 10/4, (June 2018): 219-249.

26 Ferit Yücebaş, “Cumhuriyet Döneminde Güneydoğu Anadolu (Gaziantep-Mardin-Urfa)'ya Yapılan
} 
dolayı ekmek bulamama sorunu ortaya çıkmıştır. Ceylanpınar Çiftliği’nde üretilen buğdaylar bu şehirlerdeki ekmek sıkıntısının giderilmesinde önemli rol oynamıştır. ${ }^{27}$

Bakanlar Kurulu tarafından 1950 yılında alınan bir kararla çiftçilerin buğday tohumu ihtiyaçlarının Devlet Üretme Çiftliklerinden ve Ziraat Bankası'ndan karşılanması kararlaştırılmıştır. 10 Ekim 1950 tarihli bu karar doğrultusunda Toprak Mahsulleri Ofisindeki 35.000 ton tohumun 23.000'i Devlet Üretme Çiftlikleri aracılığıyla geri kalan 12.000 tonu da Ziraat Bankası aracılığıyla çiftçilere veresiye olarak faizsiz bir şekilde dağıtılmıştır. Çitçilere dağıtılan bu tohumlar Ceylanpınar Devlet Üretme Çiftliği'nde yetiştirilen Akbaşak, Akova, Floransa ve Karakılçık cinsi tohumlardır. ${ }^{28}$ 24 Eylül 1951 tarihinde yine Bakanlar Kurulunun aldığı karar doğrultusunda 33.000 ton tohumun 20.000 tonu Devlet Üretme Çiftlikleri aracılığıyla geri kalan 13.000 tonu da Ziraat Bankası aracılığıyla çiftçilere veresiye olarak faizsiz şekilde dağıtılmıştır. ${ }^{29}$

1951-1952 yılları arasında Ceylanpınar Devlet Üretme Çiftliği’ndeki arazi miktarının toplamı 370.000 dekardır. Bu arazinin 301.758 dekarı ekili arazidir. Çiftlikteki ekili arazi miktarı 1952-53 yılları arasında 320.000 dekar, 1953-54 yılları arasında 200.000 dekar, 1954-55 yılları arasında da 100.000 dekardir. ${ }^{30}$

1962-1970 yılları arasında Ceylanpınar Çiftliği’ndeki toplam arazi miktarı 1.361.630 dönümdür. $\mathrm{Bu}$ arazinin 931.095 dönümü susuz tarla arazisi olup bu arazide nadas sistemiyle hububat ekimi yapılmıştır. 18.500 dönümünde ise sulu tarım yapılmıştır. Aynı yıllarda çiftlik arazisinin 7.295 dönümü bağ-bahçe arazisi, 403.240 dönümü mera arazisi ve 1.500 dönümü de çayır arazisi olarak kullanılmıştır. 931.095 dönümlük susuz arazide arpa, buğday ve yulaf gibi ürünler yetiştirilmiştir. ${ }^{31}$

1963 yılı fiyatlarıyla çiftliğin Gayri Safi Hasılası 46.436.513 liradır. Bu GSH’nin \% 79,4'lük kısmı bitkisel üretimden, \% 5,3'lük kısmı hayvansal üretimden ve \% 13,9'u tohum hazırlamadan ve \%1,4'lük kısmı da yan gelirlerden oluşmaktadır. Çiftliğin sabit masrafları çıkarıldıktan sonra 1963 yılındaki net geliri 17.874.081 liradır. ${ }^{32}$ Ülke genelindeki Devlet Üretme Çiftliklerinin kar ve zarar miktarları 1964 yılındaki Sayıştay raporuna yansımıştır. Bu raporda Ceylanpınar Çiftliği’nin 20.431.680,58 kuruş kâr elde ettiği belirtilmiştir. ${ }^{33}$

Kamu Harcamaları ve Yatırımlar (1923-1950)", Yayımlanmamış Doktora Tezi, Bitlis Eren Üniversitesi/ Erciyes Üniversitesi, (2018), 416-417.

27 Ragıp Ziya Mağden, Zirai Kombinalar, (Ankara: Güney Matbaacılık ve Gazetecilik T.A.O., 1949), 5354.

28 Nadir Yurtoğlu, “Türkiye'de Kırsal Kesimin Kalkınmasında Önemli Bir Model: Devlet Üretme Çiftlikleri (1949-1960)", Tarih Okulu Dergisi (TOD), 11/XXXIV. (Haziran 2018): 587-632.

29 BCA, 30.18.1.2.126.67.4, (24 Eylül 1951).

30 Nadir Yurtoğlu, “Türkiye'de Kırsal Kesimin Kalkınmasında Önemli Bir Model: Devlet Üretme Çiftlikleri (1949-1960)", Tarih Okulu Dergisi (TOD), 11/XXXIV, (Haziran 2018): 587-632.

31 Metin Çakıcı, "Ceylanpınar Devlet Üretme Çiftliği’nin Doğrusal Programlama Metodu İle Yeniden Organizasyonu”, Atatürk Üniversitesi Ziraat Fakültesi Dergisi, 4/2, (1973): 37.

32 Metin Çakıcı, "Ceylanpınar Devlet Üretme Çiftliği’nin Doğrusal Programlama Metodu İle Yeniden Organizasyonu”, Atatürk Üniversitesi Ziraat Fakültesi Dergisi, 4/2, (1973): 38.

33 TBMM, 3.Dönem, 1.Toplantı, S. Saylsı 198, Devlet Üretme Çiftlikleri Genel Müdürlüğ̈̈ Döner Sermayesi 1964 Yll Konsolide Bilançosunun Sunulduğuna Dair Sayıştay Başkanlığı Tezkeresi ve Sayıştay Komisyonu Raporu, (3/261): 14. 
1968 yılında Ceylanpınar Çiftliği’ne arpa, buğday, mısır, pamuk, mercimek, nohut, yonca ve yulaf gibi ürünler ekilmiştir. Bu ürünlerin kaç dekarlık alana ekildiği ve neticede kaç ton mahsulün hasat edildiği aşağıdaki tabloda verilmiştir.

Tablo 3. 1968'de Ceylanpınar Çiftliği’nde Ekilen Ürün Çeşitleri ve Hasat Miktarları

\begin{tabular}{|l|c|c|}
\hline Ekilen Ürün & $\begin{array}{c}\text { Ekilen Alan } \\
\text { (Dekar) }\end{array}$ & $\begin{array}{c}\text { Hasat Edilen Mahsül Miktari } \\
\text { (Ton) }\end{array}$ \\
\hline Buğday & 501.820 & 75.900 \\
\hline Arpa & 4.850 & 873 \\
\hline Yulaf & 2.000 & 300 \\
\hline Pamuk & 7.355 & 1.839 \\
\hline Nohut & \multirow{2}{*}{600} & 50 \\
\cline { 1 - 2 } Mercimek & & 50 \\
\cline { 1 - 3 } Ayçiçeği & 800 & 15 \\
\cline { 1 - 3 } Misır & 840 & 600 \\
\hline Yonca & $\mathbf{8 0 . 4 6 7}$ & 840 \\
\hline Toplam & \multicolumn{2}{|c|}{} \\
\cline { 3 - 4 }
\end{tabular}

Kaynak: İlhan Karahan, “Cumhuriyet Dönemi Devlet Üretme Çiftlikleri ve Faaliyetleri (19501985)", 93-94.

Yukardaki tabloda görüldüğü üzere 1968 yılında Ceylanpınar Çiftliği’nde 518.265 dekar araziye buğday, arpa, yulaf, pamuk, nohut, mercimek, ayçiçeği, mısır ve yonca ekilmiştir. Ekilen bu ürünlerden 80.467 ton mahsul elde edilmiştir. Yetiştirilen ürünler arasında pamuk ve misır gibi ürünlerin bulunması çiftlikte sulu tarımın yapıldığını göstermektedir.

Tablodaki ürünler dışında 1968 yılında Ceylanpınar Çiftliği’nde 103 dekarlık alanda sebzecilik, 305 dekarlık alanda meyvecilik, 248 dekarlık alanda bağ, 6 dekarlık alanda çögürlük adı verilen dikenli ağaç, 1.206 dekarlık alanda da ağaçlandırma yapılmıştır. ${ }^{34}$

Ceylanpınar Çiftliği'nde ekilen hububatın büyük çoğunluğu buğday ve arpadır. Bu ürünlerin yanında mısır, nohut ve mercimek gibi ürünler de ekilmiştir. Ekilen bu ürünlerden elde edilen verim iklim şartlarına ve yağış miktarına göre farklılık göstermiştir. Üretim alanındaki bu farklılı̆̆ ortadan kaldırması ve verimde devamlılığı sağlanması amacıyla 1971 yılında 180 su kuyusu açılmıştır. 6.000 dekarlık alan bu su kuyuları ile sulanmıştır. ${ }^{35}$ Aynı yıl 420.000 dekara deneme amacıyla ekilen "Bezostia” Sovyet buğdayından 60.000 ton buğday elde edilmiştir. ${ }^{36}$

1975-1985 yılları arasında Ceylanpınar Çiftliği’ne ekilen arpa ve buğday miktarı ile çiftliğe düşen yağış oranları aşağıdaki tabloda verilmiştir.

34 İlhan Karahan, "Cumhuriyet Dönemi Devlet Üretme Çiftlikleri ve Faaliyetleri (1950-1985)", (Yayımlanmamış Yüksek Lisans Tezi, Van Yüzüncü Yıl Üniversitesi, 2019), 93-94.

35 Milliyet Gazetesi, 10 Eylül 1971, 7.

36 Milliyet Gazetesi, 11 Eylül 1971, 7. 
Tablo 4. 1975-1985 Yılları Arasında Ceylanpınar Çiftliği’nde Ekilen Arpa ve Buğday Miktarı ve Yıllara Göre Yağış Oranları

\begin{tabular}{|c|c|c|c|c|}
\hline Yil & Ürün Cinsi & Ekilen Alan (Dekar) & $\begin{array}{l}\text { Üretilen Miktar } \\
\text { (Kg) }\end{array}$ & $\begin{array}{l}\text { Düşen Yağış } \\
\text { Miktarı } \\
(\mathrm{mm})\end{array}$ \\
\hline \multirow[t]{2}{*}{1975} & Arpa & 4.700 & 1.207 .090 & \multirow[t]{2}{*}{319} \\
\hline & Buğday & 508.253 & 17.938 .159 & \\
\hline \multirow[t]{2}{*}{1976} & Arpa & 8.802 & 1.401 .110 & \multirow[t]{2}{*}{540} \\
\hline & Buğday & 497.633 & 146.921 .180 & \\
\hline \multirow[t]{2}{*}{1977} & Arpa & 7.900 & 1.628 .130 & \multirow[t]{2}{*}{310} \\
\hline & Buğday & 464.447 & 82.121 .030 & \\
\hline \multirow[t]{2}{*}{1978} & Arpa & 9.700 & 1.822 .650 & \multirow[t]{2}{*}{335} \\
\hline & Buğday & 498.583 & 79.346 .590 & \\
\hline \multirow[t]{2}{*}{1979} & Arpa & 12.000 & 553.600 & \multirow[t]{2}{*}{307} \\
\hline & Buğday & 446.570 & 89.273 .100 & \\
\hline \multirow[t]{2}{*}{1980} & Arpa & 7.875 & 2.435 .100 & \multirow[t]{2}{*}{429} \\
\hline & Buğday & 493.283 & 29.838 .439 & \\
\hline \multirow[t]{2}{*}{1981} & Arpa & 17.211 & 2.789 .000 & \multirow[t]{2}{*}{374} \\
\hline & Buğday & 450.100 & 97.729 .930 & \\
\hline \multirow[t]{2}{*}{1982} & Arpa & 15.150 & 2.106 .470 & \multirow[t]{2}{*}{339} \\
\hline & Buğday & 501.358 & 105.185 .420 & \\
\hline \multirow[t]{2}{*}{1983} & Arpa & 16.550 & 2.602 .810 & \multirow[t]{2}{*}{315} \\
\hline & Buğday & 430.000 & 82.558 .849 & \\
\hline \multirow[t]{2}{*}{1984} & Arpa & 25.100 & 4.166 .430 & \multirow[t]{2}{*}{200} \\
\hline & Buğday & 478.058 & 85.037 .420 & \\
\hline \multirow[t]{2}{*}{1985} & Arpa & 14.533 & 1.393 .220 & \multirow[t]{2}{*}{197} \\
\hline & Buğday & 436.686 & 54.819 .190 & \\
\hline \multicolumn{2}{|c|}{ Toplam } & 5.344 .492 & 892.874 .917 & 3.665 \\
\hline
\end{tabular}

Kaynak: İlhan Karahan, “Cumhuriyet Dönemi Devlet Üretme Çiftlikleri ve Faaliyetleri (19501985)", 96-97.

Yukarıdaki tabloya göre en fazla verim 1976 yılında alınmıştır. 1976 yılında çiftliğe düşen yağış miktarı 540 mm'dir. Aynı yıl çiftlikte yetiştirilen buğday miktarı $146.921 .180 \mathrm{~kg}$ iken arpa miktarı da 1.401 .110 kg'dır. 1977 ve 1983 yıllarında çiftliğe düşen yağış miktarı azalmış olsa da buğday üretiminde ciddi bir düşüş yaşanmamıştır.

\section{6. Çiftlikte Zirai Mücadele Çalışmaları}

Devlet Üretme Çiftliklerinde tarımda verimi artırmak amacıyla zirai mücadele yoluna gidilmiş ve bu doğrultuda çeşitli yöntemler uygulanmıştır. 1950-56 yılları arasında 455.238 dekar ekili arazi uçaklarla ilaçlanmıştır. Ceylanpınar Çiftliği’ndeki 137.600 dekarda Pelemir otu ile mücadele 
edilmiştir. ${ }^{37} 1956$ yılında İtalyan Airon Şirketi, Türkiye'deki devlet üretme çiftliklerinde 170.000 dekar araziyi Pelemir, 325 hektar araziyi de sarı ottan temizlemiştir. İlaçlanan çiftlikler Altınova, Balâ, Ceylanpınar, Gözlü, Malya, Polatlı ve Ulaş Devlet Üretme Çiftliği'dir. ${ }^{38}$

Çiftliklerde yetiştirilen buğday, arpa, mısır gibi ürünler bazı yıllar çeşitli hastalıklara yakalanmıştır. Bu durum Ceylanpınar Devlet Üretme Çiftliği'ndeki ürünler içinde geçerlidir. 1969 yılında Zirai Araştırma Enstitüsü’nün Güneydoğu Anadolu'da yaptı̆̆ incelemelerde Urfa, Mardin ve Diyarbakır'da ekilen buğdaylarda ciddi miktarda pas hastalığına rastlanmıştır. Bu hastalıktan dolayı Ceylanpınar Devlet Üretme Çiftliği'nde yetiştirilen buğday çeşitlerinde önemli ölçüde kayıp yaşanmıştır. Bu kayıplar aşağıdaki tabloda verilmiştir. ${ }^{39}$

Tablo 5. 1969 Yılında Pas Hastalığından Dolayı Buğday Çeşitlerinde Yaşanan Üretim Kaybı.

\begin{tabular}{|l|l|c|l|}
\hline İşletme Adı-Parsel Numarası & $\begin{array}{c}\text { Buğday } \\
\text { Çeşidi }\end{array}$ & $\begin{array}{c}\text { Takribi Zarar } \\
(\%)\end{array}$ & \multicolumn{1}{|c|}{ Pas Türleri } \\
\hline Ceylanpınar Çiftliği - P.N. 72 & Wanser & 19 & Kahverengi Pas \\
\hline Ceylanpınar Çiftliği - P.N. 80 & Bezostia & - & Sarı-Kahverengi Pas \% 1 Rastık \\
\hline Ceylanpınar Çiftliği - P.N. 55 & Brevor & 35 & Sarı-Kahverengi Pas \\
\hline Ceylanpınar Çiftliği - P.N. 101 & Akbaşak & 12 & Kahverengi Pas \\
\hline Ceylanpınar Çiftliği - P.N. 76 & Burt & 17 & Sarı Pas \\
\hline Ceylanpınar Çiftliği - P.N. 300 & Burt & 14 & Sarı Pas \\
\hline Ceylanpınar Çiftliği - P.N. 314 & Floransa & 5 & Sarı-Kahverengi Pas \\
\hline Ceylanpınar Çiftliği - P.N. 304 & Floransa & 5 & Sarı-Kahverengi Pas \\
\hline Ceylanpınar Çiftliği - P.N. 305 & Burt & 9 & Sarı-Kahverengi Pas \\
\hline Ceylanpınar Çiftliği - P.N. 311 & Burt & 13 & Sarı-Kahverengi Pas \\
\hline Ceylanpınar Çiftliği - P.N. 306 & Burt & 14 & Sarı-Kahverengi Pas \\
\hline Ceylanpınar Çiftliği - P.N. 50 & Burt & 15 & Sarı-Kahverengi Pas \\
\hline Ceylanpınar Çiftliği - P.N. 37 & Burt & 18 & Sarı Pas \\
\hline Ceylanpınar Çiftliği - P.N. 49 & Burt & 7 & Sarı Pas \\
\hline Ceylanpınar Çiftliği - P.N. 67 & Burt & 23 & Sarı Pas \\
\hline Ceylanpınar Çiftliği - P.N. 70 & Burt & 26 & Sarı Pas \\
\hline Ceylanpınar Çiftliği - P.N. 39 & Burt & 25 & Sarı Pas \\
\hline Ceylanpınar Çiftliği - P.N. 53 & Burt & 6 & Sarı Pas \\
\hline Ceylanpınar Çiftliği - P.N. 69 & Burt & 25 & Sarı Pas \\
\hline Ceylanpınar Çiftliği - P.N. 73 & Burt & 3 & Sarı Pas \\
\hline Ceylanpınar Çiftliği - P.N. 52 & Burt & 25 & Sarı Pas \\
\hline & & & \\
\hline
\end{tabular}

37 Nadir Yurtoğlu, “Türkiye'de Kırsal Kesimin Kalkınmasında Önemli Bir Model: Devlet Üretme Çiftlikleri (1949-1960)", Tarih Okulu Dergisi (TOD), 11/XXXIV. (Haziran 2018): 587-632.

38 Devlet Üretme Çiftlikleri Genel Müdürlüğü, Ziraat Vekâleti Devlet Üretme Çiftlikleri Genel Müdürlügüne Bağlı İşletmelerde 1950-1956 Yılları Arasında Pelemir, Sarı Ot ve Diğer Yabani Otlara Karşı Tatbik Edilmiş olan Mücadele ve Usulleri ve Şekilleri”, Tomurcuk Dergisi, 6/61 (Ocak 1957): 8.

39 Yüksel Kazım Oran, Yaşar Parlak ve Yalçın Yılmazdemir, Bitki Koruma Bülteni, Doğu ve Güneydoğu Anadolu Bölgelerinde Ekilen Yerli ve Yabancı Menşeli Buğday Çeşitlerinin 1969 Yılında Pasa Yakalanma Durumları, C.11, No.4, (Aralık: 1971), 205-206. 
Kaynak: Yüksel Kazım Oran, Yaşar Parlak ve Yalçın Yılmazdemir, Bitki Koruma Bülteni, Doğu ve Güneydoğu Anadolu Bölgelerinde Ekilen Yerli ve Yabancı Menşeli Buğday Çeşitlerinin 1969

Yılında Pasa Yakalanma Durumları, 205-206.

Yukardaki tabloda Ceylanpınar Üretme Çiftliği'nde bulunan parsellerde ekilen buğday çeşitleri verilmiştir. Bu buğday çeşitleri içinde 55 numaralı parselde ekilen Brevor türü buğdayın \% 35 oranında sarı ve kahverengi pas hastalığına yakalandığı görülmektedir. Pas hastalığına yakalanmayan buğday çeşidi ise Sovyetlerden getirilen Bezostia türü buğdaydır. Bu durum Bezostia buğdayının bölge iklimine uyum sağladığını göstermektedir.

1969 yılında Zirai Araştırma Enstitüsü’nün Ceylanpınar Devlet Üretme Çiftliği’nde yaptığ1 buğday incelemeler neticesinde ürün cinsine göre pas hastalığının sebep olduğu tahmini zarar aşağıdaki tabloda verilmiştir.

Tablo 6. 1969 Yılında Ürün Cinsine Göre Pas Hastalığının Sebep Olduğu Zararın Yüzdelik Oranlar1.

\begin{tabular}{|l|l|c|l|}
\hline \multicolumn{1}{|c|}{ İşletme Adı } & Ürün Çeşidi & Tahmini Zarar (\%) & Pas Türleri \\
\hline Ceylanpınar Çiftliği & Nadodores & 3 & Sarı Pas \\
\hline Ceylanpınar Çiftliği & Floransa & 39 & Sarı Pas \\
\hline Ceylanpınar Çiftliği & Mayo 64 & - & Sarı Pas \\
\hline Ceylanpınar Çiftliği & Penjama 62 & 10 & Sarı Pas \\
\hline Ceylanpınar Çiftliği & Gaines & 18 & Sarı Pas \\
\hline Ceylanpınar Çiftliği & Bağacak & 7 & Sar1 Pas \\
\hline Ceylanpınar Çiftliği & Herkowskaya & 37 & Sar1 Pas \\
\hline Ceylanpınar Çiftliği & Cieto-Cerros & 34 & Sarı Pas \\
\hline Ceylanpınar Çiftliği & Brut & 40 & Sarı Pas \\
\hline Ceylanpınar Çiftliği & Wanser & 39 & Sar1 Pas \\
\hline Ceylanpınar Çiftliği & Bezostia & - & Pas Yok \\
\hline Ceylanpınar Çiftliği & Kösemelez & 23 & Sarı Pas \\
\hline Ceylanpınar Çiftliği & Pitik 62 & 3 & Sar1 Pas \\
\hline Ceylanpınar Çiftliği & Lermaroja & 8 & Sar1 Pas \\
\hline Ceylanpınar Çiftliği & Tevere & 9 & Sarı Pas \\
\hline
\end{tabular}

Kaynak: Yüksel Kazım Oran, Yaşar Parlak ve Yalçın Yılmazdemir, Bitki Koruma Bülteni, Doğu ve Güneydoğu Anadolu Bölgelerinde Ekilen Yerli ve Yabancı Menşeli Buğday Çeşitlerinin 1969 Yılında Pasa Yakalanma Durumlarl, 210.

Yukardaki tabloda Ceylanpınar Çiftliği’ne 1969 yılında ekilen yerli ve yabancı buğday tohumlarından hangisinin yüzde kaç oranında pas hastalığına yakalandığı gösterilmektedir. Ürün çeşitleri içinde Brut türü buğdayın \% 40, Floransa ve Wanser türlerinin \% 39 oranında sarı pas hastalığına yakalandığı görülmektedir. Bezostia türünde ise herhangi bir pas hastalığı görülmemektedir. 


\section{7. Çiftlikte Hayvancılık Faaliyetleri}

Çiftlikte tarım faaliyetlerinin yanında hayvancılık faaliyetleri de yürütülmüştür. Hayvancılık faaliyeti olarak daha çok süt sığırcılığı ve süt koyunculuğu yapılmıştır. 1951-1952 yıllarında Ceylanpınar Çiftliği'nde küçükbaş hayvancılığını geliştirmek için Arapkoyunu cinsi koyun sayısı artırılmıştır. ${ }^{40}$ Kıvırcık ırkından süt, yapağı gibi hayvansal ürünler elde etmek amacıyla farklı bölgelerden ivesi ırkı damızlık koyunlar satın alınmıştır. ${ }^{41} 1968$ yılında çiftlikte İvesi ırkına mensup koyun sayıs1 10.505 'tir. Bu koyunlardan 840 ton süt, 900 ton gübre ve $43.500 \mathrm{~kg}$ yün üretilmiştir. ${ }^{42}$

1960'lı yıllarda büyükbaş hayvancılığı geliştirmek amacıyla İngiltere'den Jersey süt ırkı ile Herefard et ırkı hayvanlar getirilmiştir. Yine aynı yıllarda Hollanda'dan Holstein Friesian süt ırk1 inekler getirilmiştir. ${ }^{43} 1971$ yılında Ceylanpınar Devlet Üretme Çiftliği'nde 70.000 koyun ve 6.000 baş sığır yetiştirilmiştir. Belirtilen yılda Türk Silahlı Kuvvetlerinin peynir ve yağ ihtiyacının büyük bir kısmı Ceylanpınar Çiftliği'nden karşılanmıştır ${ }^{44}$ Ayrıca çiftlikte kümes hayvancılığı faaliyetleri de yürütülmüştür. Nitekim 1968 y1lında çiftlikte Leghorn cinsi çok sayıda tavuk yetiştirilmiştir. Bu tavuklardan 200.000 adet yemeklik ve 5.000 adet damızlık yumurta elde edilmiştir. ${ }^{45} 1977$ yılında 5.000 tavuk "Yalancı Tavuk Vebası" hastalığına yakalanarak ölmüştür. ${ }^{46}$

\subsection{Ceylanpınar Ovasına Yeraltı Suyu İşletme Sahasının Açılması}

Karasal iklim şartlarının hâkim olduğu Ceylanpınar'da yazları sıcak ve kurak kışları ılık ve yağışlı geçmektedir. Yaz aylarının çok sıcak geçmesi Ceylanpınar'da yaşayan halkı ve çiftlikte yetiştirilen ürün çeşitliliğini olumsuz etkilemiştir. Bu duruma bir çözüm bulmak amaciyla Enerji ve Tabii Kaynaklar Bakanlığı 2 Aralık 1968'de Bakanlar Kurulu'na Ceylanpınar ovasındaki yeraltı suyu işletme sahasını faaliyete açma teklifinde bulunmuştur. Ovadaki tahmini yeraltı suyu rezervi yıllık 850 milyon $\mathrm{m}^{3}$ ’tür. Enerji ve Tabii Kaynaklar Bakanlığının bu teklifi, Bakanlar Kurulu tarafından 30 Aralık 1968'de kabul edilmiş ve Ceylanpınar Yeraltı Suyu İşletme Sahası faaliyete açılmıştır. Bakanlar Kurulunun aldığı kararda Ceylanpınar Ovası'nda 10 metre derinliğe kadar kazılacak kuyular için belge alma zorunluluğu kaldırılmıştır. 10 metreden daha derin kuyular için belge alma zorunluluğu devam ettirilmiştir. Ceylanpınar Ovası'nın yeraltı suyu işletme sahası batı, güney, doğu ve kuzey yönlerinde şu şekilde belirlenmiştir.

Batıdan: Güzelyat harabesinin 4,5 km batısı, Kazak höyüğünün 1,6 km batısı ve Tıraştepe Karakolunun 0,6 km doğusu;

Güneyden: Suriye sınırı;

40 TBMM Kanunları, Devlet Üretme Çiftlikleri Umum Müdürlüğ̈̈ 1953 Yllı Bütçe Kanunu Lâyihası ve Bütçe Komisyonu Raporu (1/478), S.Sayısı:119, (28 Kasım 1952), 8-12.

41 TBMM, 3.Dönem, 1.Toplant1, S. Sayıs1 198, Devlet Üretme Çiftlikleri Genel Müdürlüğ̈̈ Döner Sermayesi 1964 Yılı Konsolide Bilançosunun Sunulduğuna Dair Sayıştay Başkanlı̆̆ Tezkeresi ve Sayıştay Komisyonu Raporu (3/261), (Ankara 1964), 16.

42 İlhan Karahan, "Cumhuriyet Dönemi Devlet Üretme Çiftlikleri ve Faaliyetleri (1950-1985)”, 93-94.

43 TBMM, 3.Dönem, 1.Toplant1, S. Sayıs1 198, Devlet Üretme Çiftlikleri Genel Müdürlüğü Döner Sermayesi 1964 Yllı Konsolide Bilançosunun Sunulduğuna Dair Sayıştay Başkanlı̆̆ı Tezkeresi Ve Sayıştay Komisyonu Raporu (3/261), 16.

44 Milliyet Gazetesi, 11 Eylül 1971, 7.

45 İlhan Karahan, "Cumhuriyet Dönemi Devlet Üretme Çiftlikleri ve Faaliyetleri (1950-1985)", 93-94.

46 Milliyet Gazetesi, 02 Temmuz 1977, 13. 
Doğudan: Büyük Circip istasyonunun 3 km kuzeydoğusu ve Ayn-1 Seraç Karakolu'nun 6 $\mathrm{km}$ doğusu

Kuzeyden: Ayn-1 Seraç harabesinin 4 km kuzeyi, Küçük Circip Karakolu’nun 5 km batısı ve Güzelyat harabesinin 3,4 km kuzeyi ile sınırlandırılmıştır. ${ }^{47}$

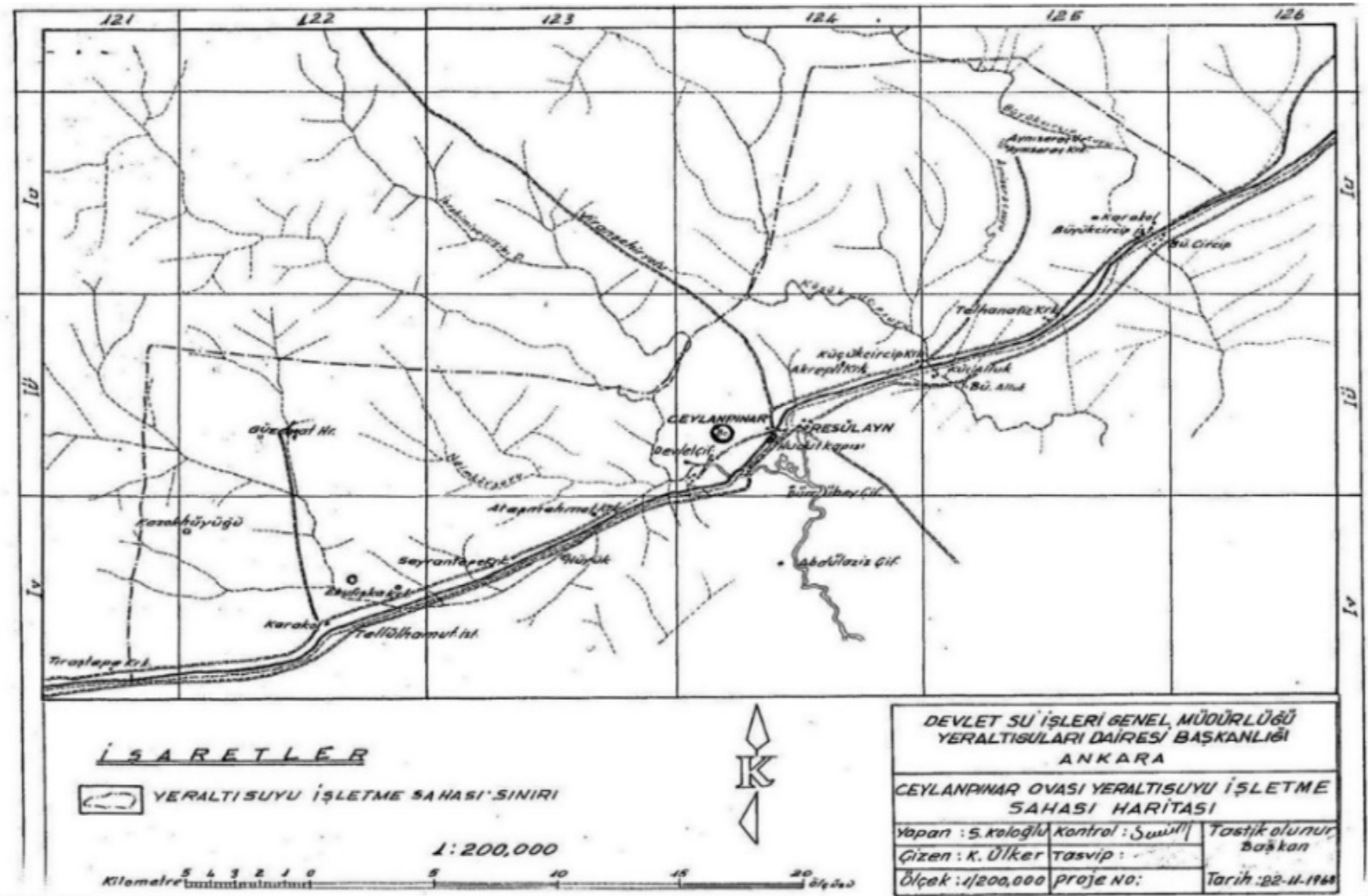

Kaynak: BCA, 30.18.1.2/228.92.5, 30 Aralık 1968.

Ceylanpınar Ovası'na yeraltı suyu işletme sahasının açılması, Ceylanpınar ve çevresinde ürün çeşitliliğinin artmasına neden olmuştur. Daha önce Ceylanpınar Ovası'nda buğday, arpa ve mercimek gibi ürünler yetiştirilirken 1968'de yeraltı suyu işletme sahalarının açılmasıyla pamuk, ayçiçeği ve mısır gibi ürünlerde yetiştirilmeye başlanmıştır.

\section{9. Çiftlikte Haberleşme Sorununun Çözülmesi}

Ceylanpınar Çiftliği, 1 milyon 761 bin dekar arazi varlığı ile Türkiye'nin en büyük ve en geniş tek parça tarım işletmesidir. ${ }^{48} \mathrm{Bu}$ arazi üzerinde üretimin sağlıklı bir şekilde yapılabilmesi ve ekiplerin birbiriyle uyum içinde çalışması için bir haberleşme sistemine ihtiyaç duyulmuştur. Bu ihtiyacın giderilmesi için Ceylanpınar Çiftliği'ne 5 Ağustos 1970 tarihinde Bakanlar Kurulu kararıyla bir adet verici telsiz cihazı ve bir adet alıcı telsiz cihazı satın alınmıştır. Alınan bu cihazlarla Ceylanpınar Çiftliği içerisinde ve çevresinde 90 km'lik alanda haberleşme sağlanmıştır. ${ }^{49}$

47 BCA, 30.18.1.2/228.92.5, (30 Aralık 1968).

48 Tarım İşletmeleri Genel Müdürlüğü, Ceylanpınar Çiftliği-Dünden Bugüne Tigem (Türk Toplumunun Yüz $A k l), 72$.

49 BCA, 30.18.1.2/255.59.2, (05 Ağustos 1970). 


\subsection{0. Çiftlik Gelirlerinden Viranşehir Ziraat Odasına Aidatın Ödenmesi}

4 Eylül 1959 tarihinde Resmi Gazetede yayınlanan Ziraat Odaları Birliği tüzüğünün 32. maddesi gereğince Devlet Üretme Çiftliklerinin bünyesinde bulunan çiftliklerin, bağlı bulundukları Ziraat Odalarına çiftlik gelirleri üzerinden belli bir miktar yıllık aidat ödenmesi kararlaştırılmıştır. Ceylanpınar Devlet Üretme Çiftliği, 1965-1969 yılları arasında Viranşehir Ziraat Odasına ödemesi gereken yıllık aidatı ödemediği için bu durum Viranşehir Ziraat Odası tarafindan mahkemeye taşınmıştır. Danıştay 3. Dairesi tarafından hazırlanan bilirkişi raporlarında Ceylanpınar Devlet Üretme Çiftliği'nin haksız olduğu ve Viranşehir Ziraat Odasına ödemesi gereken 949.273.04 lira anapara ile 18.945.46 lira gecikme zammını ödemesi gerektiği belirtilmiştir. Alacaklı durumda olan Viranşehir Ziraat Odası, 11 Mayıs 1976 tarihi itibarıyla faizleriyle birlikte 1.288.263.12 liraya ulaşan alacağı için Ceylanpınar Üretme Çiftliği'nin 500.000 lira ödenmesi halinde sulh olabileceklerini Danıştay’a bildirmiştir. Viranşehir Ziraat Odası'nın bu teklifi, Devlet Üretme Çiftliği Genel Müdürlüğünün 19 Ekim 1978 günü aldığı kararla karşılıklı olarak dava ve icra takiplerinden vazgeçilmesi şartıyla kabul edilmiştir. Her iki tarafın 500.000 lirada anlaşması üzerine Danıştay 3. Dairesi 26 Ocak 1979'da aldığı kararla her iki kurumun 500.000 lirada anlaşması yönünde karar vermiştir. ${ }^{50}$

\subsection{1. Çiftlik Arazisinin Topraksız Köylüye Dağıtılması}

Devlet, konargöçer durumda olan göçebeleri yerleşik hayata geçirmek, vergileri düzenli bir şekilde toplamak, boş arazileri tarıma açmak ve üretimi artırmak amacıyla belli dönemlerde elindeki toprakların bir kısmını Bakanlar Kurulu kararıyla topraksız köylüye dağıtmıştır. Bu yolla hem vergi temini hem de üretimde süreklilik ve artış sağlanmıştır.

19 Ocak 1952’de Cumhurbaşkanı Celal Bayar ve Başbakan Adnan Menderes'in katıldığ Bakanlar Kurulunda Ceylanpınar'daki çiftlik arazisinin uygun yerlerinden 500.000 dekar arazinin topraksız veya az topraklı çiftçiye dağıtılması kararlaştırılmıştır. ${ }^{51} \mathrm{Bu}$ durum konargöçer olup hayvancılıkla uğraşan halkın yerleşik hayata geçmesini hızlandırmıştır.

Ceylanpınar ilçesine bağlı Tekinler köyünde oturan Ahmet Pilis, devletin kendilerine 1978 yılında toprak dağıttığını, çiftlik arazisi üzerinde bulunan Akbulut, Ceylan, Damlacık, Dikili, Gümüş, Işıklar, Karataş, Muratlı, Tekinler, Yalçınkaya ve Yukarı Taşlıdere köylerinde oturan köylünün 1978'deki bu toprak dağıtımından faydalandığını ve kendisinin de bu dağıtım sırasında 119 dönüm susuz arazi aldığını ifade etmiştir. ${ }^{52}$

\subsection{2. Çiftlik Arazisinden Gümrük ve Tekel Vekâletine Arazi Devri}

Ekim 1944'te Rasulayn Çiftliği'ndeki Tel-Hamut İstasyonu'nun 2 km kuzeybatısında bulunan Ziraî Kombinalar civarındaki tohumluk buğdayı çalmak isteyen 7 Suriyeli yanlarında 19 merkep, 16 deve ve 1 at getirmişlerdir. Bu hırsızlık girişimini önceden haber alan Rasulayn Jandarma Bölüğü hırsızları yakalamak için pusu kurmuştur. Jandarmayla hırsızlar arasında meydana gelen çatışmada hırsızlara ait 6 merkep, 1 at ve 1 deve vurulmuş, 13 merkeple 15 deveye de el konulmuştur. Rasulayn ve çevresinde kaçakçılığın önlenmesi ve emniyetin sağlanması için

\footnotetext{
50 BCA, 030.11.1.0/501.31.6. (24 Nisan 1979)

51 BCA, 30.18.01/127.103.7, (19 Şubat 1952).

52 Ahmet Pilis, Tekinler Köyü, (G.T. 27 Haziran 2018).
} 
1945 yılında Mardin ve Urfa vilâyetlerine ikişer arazi otomobilinin alınması kararlaştırılmıştır. ${ }^{53}$

Ceylanpınar, Türkiye ile Suriye sınırında yer alan bir yerleşim birimidir. Bu sınır nahiyesinden kaçak girişleri engellemek ve ticareti kontrol altına almak amacıyla çiftlik arazisinden 17 Haziran 1952 'de 1000 m² $^{2}$ arazi $^{54}$ ve 30 Ocak 1953'te de Cumhurbaşkanı Celal Bayar'ın imzası ve Bakanlar Kurulunun kararıyla $34.000 \mathrm{~m}^{2}$ arazi Gümrük ve Tekel Vekâletine devredilmiştir. ${ }^{55}$

\subsection{Ceylanpınar Devlet Üretme Çiftliği’nde İşçi Eylemleri}

1968 yılının mart ayında Türk-İş Sendikası 22 Devlet Üretme Çiftliği'nde çalışan sendika üyeleriyle greve gitme kararı almıştır. ${ }^{56}$ Aynı yıl Keban Barajı'nın inşası sırasında toprakları su altında kalacak çiftçilerin geçimlerini temin etmeleri için bazı öneriler sunulmuştur. Bu önerilerden biri de çiftçilerin sanayi kuruluşlarında çalıştırılmasıdır. Bu teklif uygun görülmeyince Muş’ta bulunan Alparslan ve Urfa'da bulunan Ceylanpınar Devlet Üretme çiftliklerinden bu çiftçiler toprak verilmesi gündeme gelmiştir. Bu durumun gündeme gelmesi üzerine Türk-İş ve Tarım-İş sendikalarının idarecileri Devlet Üretme Çiftliklerinin topraklarının çiftçiye dağıtılmasına karşı çıkmış ve grev haklarını kullanacaklarını ifade etmişlerdir. ${ }^{57}$

1972 yılında Ceylanpınar Devlet Üretme Çiftliği’nde bulunan 2.202 işçi çeşitli gerekçelerle greve gitmiştir. Çiftlik idaresi işçilerden grevi sonlandırmalarını istemiş, aksi takdirde işten çıkarılacaklarını belirtmiştir. Bu durum üzerine 835 işçi 1 Nisan 1972 tarihinde greve son vererek görevine dönmüştür. Geri kalan 1.367 işçi greve devam etmişse de bir süre sonra onlar da grevi bırakarak işlerine dönmüştür. ${ }^{58}$

1978 yılında sendikalarla yöneticiler arasında yürütülen toplu iş sözleşmesi görüşmeleri sonuçsuz kalmıştır. Bu durum üzerine DİSK'e bağlı Tarım İş Sendikası kendisine bağlı işçilerle birlikte pasif direniş başlatmıştır. İşçilerin bu eylemi yaklaşmış olan buğday hasadını tehlikeye düşürdüğü için çiftlik idarecileri işçilerin pasif direnişe son vermesini istemiştir. $\mathrm{Bu}$ çağrıya olumsuz cevap verilmesi üzerine işçilerin sözleşmelerinin fesih edileceği belirtilince pasif direniş greve dönüşmüştür. Hatta bazı sendika yöneticileri ve şube başkanları hakkında tutuklama kararı çıkarılmıştır. ${ }^{59}$ Bu grev, Tarım ve Hayvancılık Bakanı Mehmet Yüceler ve Çalışma Bakanı Ahmet Bahir Ersoy'un girişimleri neticesinde 3 Temmuz 1978 'de son bulmuştur. ${ }^{60}$

\subsection{4. Çiftlik Arazisinde Petrol Arama Çalışmaları}

1975 yılında Türkiye Petrolleri Anonim Ortaklığ 1 ve bir Alman şirketi olan “A bir yıl boyunca birlikte yürüttüğü petrol arama faaliyetleri neticesinde Türkiye'nin buğday ambarı olan Ceylanpınar Devlet Üretme Çiftliği'ndeki Beyazkule bölgesinde petrol kaynağı bulunmuştur.

53 Kamu Harcamaları ve Yatırımlar (1923-1950)", Yayımlanmamıs Doktora Tezi, Bitlis Eren Üniversitesi/ Erciyes Üniversitesi, (2018), 314.

54

55

56

57

BCA, 30.18.1.2/129.52.11, (17 Haziran 1952).

BCA, 30.18.01/131.7.3, (30 Ocak 1953).

Milliyet Gazetesi, 24 Mart 1968, 7.

Milliyet Gazetesi, 25 Kasım 1968, 1.

Milliyet Gazetesi, 02 Nisan 1972, 1.

Milliyet Gazetesi, 01 Temmuz 1978, 14.

Milliyet Gazetesi, 04 Temmuz 1978, 14. 
Bu kaynak zengin petrol rezervisine sahip olduğu için sondaj çalışmalarının kısa sürede yapılması kararlaştırılmıştır. Ayrıca çiftlik ve çevresindeki 4 milyon dekarlık arazide petrol araştırmalarına devam edilmiştir. ${ }^{61}$

\subsection{Ceylanların Çiftlikte Korumaya Alınması}

Ceylanların 1950 ve 60’lı yıllarda Ceylanpınar, Harran ve Suruç arasında sürüler halinde dolaştığı bilinmektedir. Sürüler halinde gezen bu ceylanların sayıları kaçak avlanma yüzünden iyice azalmıştır. Bu durum üzerine 1968 yılında bölgedeki ceylanların sayılarını tespit etmek amacıyla ilk kez resmi çalışmalar başlatılmıştır. ${ }^{62}$

1973 yılında kuraklıktan dolayı Ceylanpınar' daki ceylanlar susuz kalmıştır. Bu olumsuz durumun giderilmesi için Ceylanpınar Devlet Üretme Çiftliği'nden tankerlerle ceylanların toplu olarak yaşadığı ve su içtiği yerlere su taşınmıştır. ${ }^{63}$

1977 yılında Ceylanpınar ve çevresinde ceylan sayısının iyice azalması üzerine idareciler tarafından bu duruma çözüm bulma amacıyla çeşitli kararlar almıştır. Bu kararlar:

Ceylanların avlanmasının yasaklanması,

Ceylanları avlayanlara çeşitli cezai müeyyideler uygulanması,

Ceylanpınar Çiftliği içinde ceylanlar için bir yaşam alanı oluşturulması,

Çiftlikteki ceylanların bakımı için bakıcı ve veterinerlerin işe alınmasıdır.

Alınan bu kararlar doğrultusunda 1977 'de çiftlik arazisine 23 adet ceylan bırakılmıştır. Koruma altındaki bu ceylanların sayısı her geçen yıl daha da artmış ve 2013 yılında çiftlikteki ceylan sayısı 1000'i aşmıştır. ${ }^{64}$

\subsection{6. Çiftlik Arazisine Türkmenlerin Yerleştirilmesi}

Ceylanpınar ve çevresine farklı tarihlerde çeşitli iskânlar gerçekleştirilmiştir. Çoğunlukla devlet tarafından gerçekleştirilen bu iskânların sosyal, ekonomik, hukuki, dini, kültürel ve siyasi birçok sebebi bulunmaktadır.

1850-56 yılları arasında Doğu Türkistan ve Pakistan'dan Türk asıllı aileler Türkiye’ye getirilmiştir. ${ }^{65}$ Ceylanpınar'a iskân edilen Doğu Türkistan göçmenlerinden 92 aileye çiftlikten arazi tahsis edilmiş ve evlerini yapmaları için 18 Ağustos 1956 ' da kerestelik tomruk verilmiştir. ${ }^{66}$

1982'de SSCB’nin Afganistan’ı işgali sırasında 7. Cumhurbaşkanı Kenan Evren'in izniyle, Türkiye'ye getirilen Afgan, Özbek ve Kazak aileler ilk önce Adana’ya yerleştirilmiştir. Oradan da bir kısmı Tokat ilinin Artova ilçesine, Kırşehir ilinin Çiçekdağı ilçesine, Sivas ilinin Ulaş ilçesine ve Urfa ilinin Ceylanpınar ilçesine yerleştirilmiştir. Ceylanpınar ilçesine yerleştirilen Afganlar ilk başta Diyarbakır'a yerleştirilmiş ve orada 4 yıla yakın bir süre kaldıktan sonra 1986

\footnotetext{
61 Milliyet Gazetesi, 25 Temmuz 1975, 9.

62 tigem.gov.tr/ceylancilik (E.T. 30.08.2020)

63 Milliyet Gazetesi, 04 Nisan 1973, 9.

64 Tarım İşletmeleri Genel Müdürlüğü, Ceylanpınar Çiftliği-Dünden Bugüne Tigem (Türk Toplumunun Yüz Akl), 92.

65 BCA, 030.18.1.2/128.19.6.1, (13 Mart 1952).

66 BCA, 30.18.1.2/144.70.3, 18 Ağustos 1956.
} 
yılında Ceylanpınar'a getirilmiştir. Ceylanpınar'daki çiftlik arazisine yerleştirilen bu ailelerin 212 hanesi Özbek kökenli Afgan iken 2 hanesi de Kazak kökenlidir. Türk Devleti, bu aileler için 214 hane, 1 okul ve 1 camiden oluşan bir köy inşa etmiştir. Köye yerleştirilen her haneye geçimlerini sağlamaları için çiftlik arazisinden 20 dönüm tarla ve bir büyükbaş hayvan verilmiştir. Ayrıca tarlalarını sürmeleri için 45 ailenin kullanımına bir traktör verilmiş ve tüm aileler 15 yıl vergiden muaf tutmuştur. ${ }^{67}$

\section{Sonuç}

20. yüzyılda Ortadoğu'da önemli siyasi gelişmeler meydana gelmiştir. I. Dünya Savaşı’ndan sonra Osmanlı toprakları itilaf devletleri arasında paylaşılmış ve bu doğrultuda sınırlar değişmiştir. Yeni kurulan Türk Devleti, sınır problemlerini çözmek için birçok girişimde bulunmuştur. Bu doğrultuda Suriye'yi işgal eden Fransa ile 20 Ekim 1921'de Ankara Antlaşması imzalanmıştır. Bu antlaşmayla Rasulayn tren hattı Türkiye ve Suriye arasında sınır kabul edilmiş, böylece Rasulayn ikiye bölünmüştür. Tren hattının kuzeyinde kalan kısım Türk Devleti’ne bırakılmıştır.

Türk Devleti, kendisine bırakılan kısımda önemli ölçüde kurumsallaşma ve iktisadi gelişme yoluna gitmiştir. Bu doğrultuda 1937'de Zirai Kombinalar kurulmuştur. Kurulan bu kombinalara bağlı olarak 1943'te Türkiye tarafında kalan Rasulayn toprakları üzerinde "Zirai Kombinaları Urfa Grup Amirliğgi” oluşturulmuştur. 1946'da Tarım Bakanlığının teklifi üzerine çiftliğin adı "Ceylanpınar Çiftliği ” olarak değiştirilmiştir. Sonraki yıllarda üretimde verimi ve kaliteyi artırmak amacıyla makineleşmeye gidilmiştir. Amerika ve Avrupa ülkelerinden traktör ve benzeri tarım makineleri ve aletleri getirilmiştir. Verimi artırmak için yurt dışından gübre, ilaç ve tohum itahlatı yapılmıştır. Tarımla birlikte hayvancılığı geliştirmek amacıyla yine yurt dışından canlı sığır ve koyun ithalatı gerçekleştirilmiştir. 1977 yılında nesli tükenmek üzere olan ceylanlar koruma altına alınmış ve çiftlikte onlar için özel bir yaşam alanı oluşturulmuştur. Böylece nesli tükenmekte olan ceylanlar yok olmaktan kurtarılmıştır.

Bölgeye yönelik iskan faaliyetleri Osmanlı'da olduğu gibi Türkiye Cumhuriyeti döneminde de devam etmiştir. Bu doğrultuda 1850-56 yılları arasında Doğu Türkistan ve Pakistan'dan, 1986 yılında da Afganistan'dan getirilen Türk asıllı aileler Ceylanpınar'a yerleştirilmiştir. Devlet, bu ailerlere geçimlerini sağlamaları için çiftlik arazisinden toprak vermiş ve onları belli bir süreliğine vergiden muaf tutmuştur. Bu yolla bölgedeki sosyo-ekonomik yapıyı korumaya çalışmıştır.

\section{Kaynakça}

\section{Arşiv Belgeleri}

BCA, 30.18.1.1/9.19.13, (03 Nisan 1340).

BCA, 30.11.1.0.10.6.1, (15 Şubat 1925).

BCA, 30.10.0.0.146.42.3, (07 Nisan 1925).

BCA, 30.11.1.0.45.43.4, (16 Ocak 1929).

BCA, 30.18.01.02.3.22.11, (17 Nisan 1929).

BCA, 30.11.01/54.8.3, (17 Mart 1930).

67 Amanullah Kaya, Afganistan Baglan Vilayeti, (G.T: 02.03.2018); Görüşülen şahıs, Ceylanpınar’a yerleşen Özbek kökenli Afganlardandır. 
BCA, 30.11.01/54.8.3, (18 Mart 1930).

BCA, 30.11.01/182.13.11, (11 Nisan 1946).

BCA, 30.18.1.2.126.67.4, (24 Eylül 1951).

BCA, 30.18.01/127.103.7, (19 Şubat 1952).

BCA, 30.18.01/131.7.3, (30 Ocak 1953).

BCA, 30.18.1.2/144.70.3, (18 Ağustos 1956).

BCA, 30.11.01/275.13.6, (08 Nisan 1959).

BCA, 30.18.1.2.210.66.10, (02 Eylül 1967).

BCA, 30.18.1.2/228.92.5, (30 Aral1k 1968).

BCA, 30.18.1.2/255.59.2, (05 Ağustos 1970).

BCA, 30.18.1.2/259.81.15, (18 Kasim 1970).

BCA, 030.11.1.0/501.31.6, (24 Nisan 1979).

BCA, 30.11.1.0/104.17.10, (3 Haziran 1936).

BCA, 30.18.1.2/128.19.6.1, (13 Mart 1952).

BCA, 30.18.1.1/5.17.10, (25 Mayıs 1338).

BCA, 30.1.0.0.81.513.4, (00.00.1965).

BCA, 30.18.1.2/129.52.11, (17 Haziran 1952).

\section{Gazeteler}

Resmi Gazete, Sayı No: 7231, 13 Haziran 1949.

Milliyet Gazetesi, 24 Mart 1968, 7.

Milliyet Gazetesi, 25 Kasim 1968, 1.

Milliyet Gazetesi, 10 Eylül 1971, 7.

Milliyet Gazetesi, 11 Eylül 1971, 7.

Milliyet Gazetesi, 11 Eylül 1971, 7.

Milliyet Gazetesi, 02 Nisan 1972, 1.

Milliyet Gazetesi, 02 Temmuz 1977, 13.

Milliyet Gazetesi, 01 Temmuz 1978, 14.

Milliyet Gazetesi, 04 Temmuz 1978, 14.

\section{İnceleme ve Araştırma Eserler}

Atar, Elif ve M. Fatih Eslemez. Ceylanpınar'ın İlçe Durum Raporu. Şanlıurfa: Karacadağ Kalkınma Ajansı Yayınları. 2011.

Çakıcı, Metin. “Ceylanpınar Devlet Üretme Çiftliği’nin Doğrusal Programlama Metodu İle Yeniden Organizasyonu,” Atatürk Üniversitesi Ziraat Fakültesi Dergisi, 4/2, (1973): 37. 
Devlet Üretme Çiftlikleri Genel Müdürlüğü, “'Ziraat Vekâleti Devlet Üretme Çiftlikleri Genel Müdürlüğüne Bağlı İşletmelerde 1950-1956 Yılları Arasında Pelemir, Sarı Ot ve Diğer Yabani Otlara Karşı Tatbik Edilmiş olan Mücadele ve Usulleri ve Şekilleri’, Tomurcuk Dergisi, C. 6, 6/61, (Ocak 1957): 8.

Karahan, İlhan. "Cumhuriyet Dönemi Devlet Üretme Çiftlikleri ve Faaliyetleri (1950-1985)." Yayımlanmamış Yüksek Lisans Tezi, Van Yüzüncü Yı1 Üniversitesi, 2019.

Oran, Yüksel Kazım, Yaşar Parlak, ve Yalçın Yı1mazdemir. "Doğu ve Güneydoğu Anadolu Bölgelerinde Ekilen Yerli ve Yabancı Menşeli Buğday Çeşitlerinin 1969 Yılında Pasa Yakalanma Durumları," Bitki Koruma Bülteni, C.11, (Aralık 1971): 205-206.

Ragıp Ziya Mağden, Zirai Kombinalar, Güney Matbaacılık ve Gazetecilik T.A.O., Ankara, 1949, s.53-54.

Tarım İşletmeleri Genel Müdürlügü. Ceylanpınar Çiftliği-Dünden Bugüne Tigem (Türk Toplumunun Yüz Akl). Ankara: TİGM Yayınları, 2013.

TBMM Kanunlar Dergisi, 2.Dönem Kanunları, 11.Cilt, 21.Birleşim, s.116.

TBMM Kanunları. Devlet Üretme Çiftlikleri Umum Müdürlüğü 1953 yılı Bütçe kanunu lâyihası ve Bütçe Komisyonu Raporu (1/478), S.Sayısı:119, (28 Kasım 1952).

TBMM, 3.Dönem, 1.Toplantı, S. Sayısı 198, Devlet Üretme Çiftlikleri Genel Müdürlüğ̈̈ Döner Sermayesi 1964 Yılı Konsolide Bilançosunun Sunulduğuna Dair Sayıştay Başkanliğı Tezkeresi ve Saylştay Komisyonu Raporu (3/261): 16.

Tekeli, İlhan ve Selim İlkin. 1929 Dünya Buhranında Türkiye ’nin İktisadi Politika Arayışları. Cilt: 1, İstanbul: Bilge Kültür Sanat Yayınevi, 2009).

Yurtoğlu, Nadir. "Cumhuriyet Dönemi Ziraatta Makineleşme Sürecinde Türkiye Zirai Donatım Kurumunun (TZDK) Yeri ve Önemi (1943-1960)," Tarih Okulu Dergisi, XXIX, (Mart 2017): 282 .

Yurtoğlu, Nadir. "II. Dünya Savaşı Dönemi ve Sonrasında Ziraî Kombinalar Tarihi Hakkında Bir İnceleme (1937-1949)," international Journal Of History Studies, 10/4, (June 2018): 219-249.

Yurtoğlu, Nadir. “Türkiye'de Kırsal Kesimin Kalkınmasında Önemli Bir Model: Devlet Üretme Çiftlikleri (1949-1960)," Tarih Okulu Dergisi (TOD), 11/XXXIV, (Haziran 2018): 587632.

Yücebaş, Ferit. “Cumhuriyet Döneminde Güneydoğu Anadolu (Gaziantep-Mardin-Urfa)'ya Yapılan Kamu Harcamaları ve Yatırımlar (1923-1950)." Yayımlanmamış Doktora Tezi, Bitlis Eren Üniversitesi/Erciyes Üniversitesi, 2018.

\section{Görüşmeler}

Ahmet Pilis, Ceylanpınar/Tekinler Köyü, 1949 doğumlu, Görüşme Tarihi: 27 Haziran 2018.

Amanullah Kaya, Afganistan/Baglan Vilayeti, 1958 doğumlu, Görüşme Tarihi: 02.03.2018. İnternet Siteleri tigem.gov.tr/ceylancılık (Erişim Tarihi 30.02.2020) 